

\title{
Ten years in the dump: An updated review of the Miocene primate-bearing localities from Abocador de Can Mata (NE Iberian Peninsula)
}

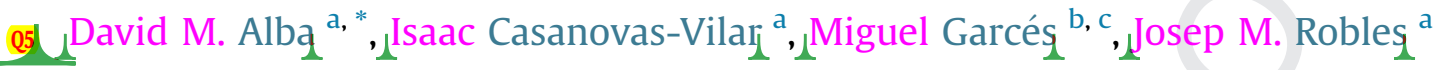 \\ ${ }^{a}$ Institut Català de Paleontologia Miquel Crusafont, Universitat Autònoma de Barcelona, Edifici ICTA-ICP, Carrer de les Columnes s/n, 08193, Cerdanyola del \\ Vallès, Barcelona, Spain \\ b Departament de Dinàmica de ta Terra i de l'Oceà, Facultat de Geologia, Universitat de Barcelona, Martí i Franqués s/n, 08028, Barcelona, Spain \\ ${ }^{\mathrm{c}}$ Institut Geomodels, Grup de Recerca Consolidat de Geodinàmica i Anàlisi de Conques, Universitat de Barcelona, Martí $i$ Franqués s/n, 08028, Barcelona, \\ Spain
}

\section{A R T I C L E I N F O}

\section{Article history:}

Received 2 May 2016

Accepted 21 September 2016

Available online $\mathrm{xxx}$

\section{Keywords:}

Hominoideae

Pliopithecoideae

Fossil primatese

Valès-Penedès Basine

Paleomagnetismo

Magnetostratigraphye

\begin{abstract}
A B S T R A C T
More than ten years of paleontological fieldwork during the enlargement of the Can Mata Landfill (Abocador de Can Mata $[\mathrm{ACM}]$ ), in els Hostalets de Pierola (Vallès-Penedès Basin, NE Iberian Peninsula) led to the recovery of $>60,000$ Miocene vertebrate remains. The huge sampling effort (due to continuous surveillance of heavy machinery digging activity, coupled with manual excavation and screen-washing of sediments) enabled generally rare faunal elements such as pliopithecoid and hominoid primates to be found. Thanks to detailed litho-, bio- and magnetostratigraphic controls, accurate dating is possible for all the recovered primate remains from 19 of the 235 localities defined along the $234 \mathrm{~m}$-thick composite stratigraphic sequence of the ACM. Here we report updated estimated (interpolated) ages for these paleontological localities and review the timing of the primate succession in this area. Our results indicate that the whole ACM sequence is late Aragonian in age (MN6 and MN7+8) and includes seven magnetozones that are correlated to subchrons C5Ar.1r to C5r.2r (ca. 12.6 to $11.4 \mathrm{Ma}$ ). Great apes (dryopithecines) are first recorded at 12.4-12.3 Ma, but most of the finds (Anoiapithecus, Pierolapithecus and Dryopithecus) cluster between 12.0 and 11.9 Ma, followed by some indeterminate dryopithecine remains between 11.7 and 11.6 Ma. Pliopithecoids first appear at $12.1 \mathrm{Ma}$, being subsequently represented by Pliopithecus between 11.9 and $11.7 \mathrm{Ma}$. The small-bodied hominoid Pliobates is the youngest ACM primate, with an estimated age of $11.6 \mathrm{Ma}$. Although these primates probably overlapped in time, their co-occurrence is recorded only twice, at $11.9 \mathrm{Ma}$ (a dryopithecine with Pliopithecus) and at 11.6 Ma (a dryopithecine with Pliobates). The rare co-occurrence between great apes and small-bodied catarrhines might be attributable to sampling biases and/or to presumed diverging ecological preferences of these groups. In the future, more detailed analyses of the fauna recovered from the long and denselysampled ACM sequence will hopefully throw new light on this long-standing, unresolved question.
\end{abstract}

๑) 2016 Elsevier Ltd. All rights reserved.

\section{Introduction}

The fossiliferous area of els Hostalets de Pierola (Vallès-Penedès Basin, NE Iberian Peninsula) is exceptional among the European Miocene in terms of the high diversity of extinct catarrhines recorded in a densely sampled stratigraphic sequence spanning more than one million years (Alba et al., 2011a). Paleontologist

\footnotetext{
* Corresponding author.

E-mail address: david.alba@icp.cat (D.M. Alba).
}

Josep R. Bataller, together with amateur collector Màrius Guerín, surveyed the area during the 1920s and first reported on its fossil fauna (Bataller Calatayud, 1938). Although Guerín collected a hominoid $\mathrm{M}^{2}$, it was mistaken for a suid and it was not reassigned to Dryopithecus until much later (van der Made and Ribot, 1999). Subsequent surveys in the area were carried out by paleontologists Miquel Crusafont and Josep F. de Villalta during the 1940s (e.g., Villalta Comella and Crusafont Pairó, 1941a; Crusafont Pairó, 1944; Villalta and Crusafont, 1946). In the loosely-defined locality of Can Vila, these authors discovered a hominoid mandibular fragment with $\mathrm{M}_{2}-\mathrm{M}_{3}$ (Villalta Comella and Crusafont Pairó, 1941b, 
1944), first attributed to Dryopithecus fontani but subsequently used to erect Sivapithecus occidentalis (currently considered a nomen dubium; Moyà-Solà et al., 2004; Alba, 2012), as well as one or two additional molar crown fragments (Villalta Comella and Crusafont Pairó, 1944; Crusafont Pairó, 1958; see discussion in; Golpe Posse, 1982; Alba et al., 2013). Many years later, CrusafontPairó and Golpe-Posse (1973) reported a female lower canine from Can Mata 1, which was formerly attributed to Hispanopithecus laietanus (e.g., Golpe Posse, 1993), but most recently assigned to Hominidae indet. (Alba, 2012).

For many years, Can Vila and Can Mata 1 were the only late Aragonian (late middle to early late Miocene) primate-bearing localities from the Penedès sector of the Vallès-Penedès Basin (Agustí et al., 1985; Casanovas-Vilar et al., 2011a). This situation drastically changed in late 2002 thanks to the beginning of paleontological surveillance, sampling and excavation associated with the removal of thousands of tons of Miocene sediments with heavy machinery during the building of a new phase of the Can Mata Landfill (Abocador de Can Mata [ACM]; Fig. 1a; Alba et al., 2006, 2009, 2011a). This paleontological work, carried out almost uninterruptedly (10.5 years of fieldwork in total) until early 2014, led to the recovery of more than 60,000 fossil vertebrate remains. This huge sampling effort enabled the recovery of rare taxa such as primates, leading to the description of three new hominoid genera (Moyà-Solà et al., 2004, 2009a; Alba et al., 2015) and a new pliopithecoid species (Alba et al., 2010). Detailed litho-, bio- and magnetostratigraphic control further enabled accurate dating of the more than 200 paleontological localities formally defined along the composite stratigraphic sequence of ACM (Moyà-Solà et al., 2009b; Casanovas-
Vilar et al., 2011a). Although estimated ages have already been published for some of them (e.g., Casanovas-Vilar et al., 2011a, 2016; Alba, 2012), recent refinements in the calibration of the geomagnetic polarity time scale (Ogg, 2012; Hilgen et al., 2012) and additional field data have resulted in minor readjustments. The termination of fieldwork in 2014 offers a good opportunity to report a comprehensive list of updated estimated ages for ACM localities, thereby including an accurate dating for all of the identified primate remains that have been recovered from this area.

\section{Geological background}

The middle to late Miocene successions in the area of els Hostalets de Pierola are located in the Penedès sector of the VallèsPenedès Basin. The latter is an elongated and NNE/SSW-oriented half-graben, situated between the Pre-littoral and the Littoral Catalan Coastal Ranges, which originated due to the rifting of the NW Mediterranean during the Neogene (Cabrera et al., 2004; de Gibert and Casanovas-Vilar, 2011). Except for some marine and transitional sequences from the early to middle Miocene, most of the basin infill consists of alluvial fan sediments that have provided a rich record of early to late Miocene continental vertebrates (Agustí et al., 1985; Casanovas-Vilar et al., 2011b, Z015). The thick Miocene alluvial sequences of the ACM and surrounding areas mostly consist of reddish to brown mudstones, coupled with less abundant sandstones, breccias and conglomerates, which were deposited in the distal-to-marginal inter-fan zones of the coalescing alluvial fan systems of Olesa and els Hostalets de Pierola (Casanovas-Vilar et al., 2008; Alba et al., 2009, 2011a; Moyà-Solà
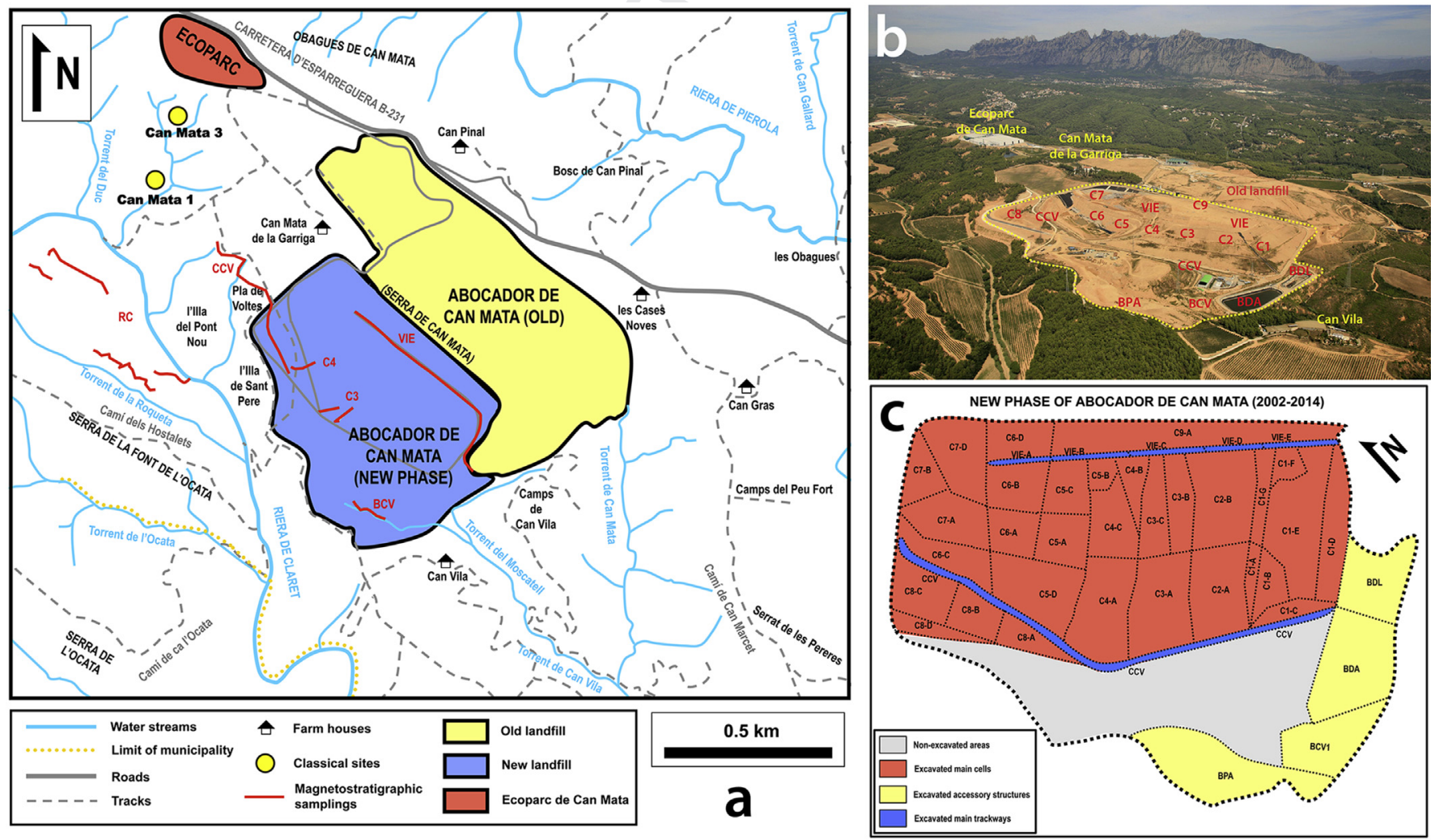

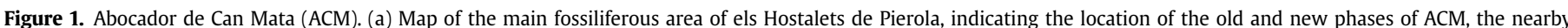

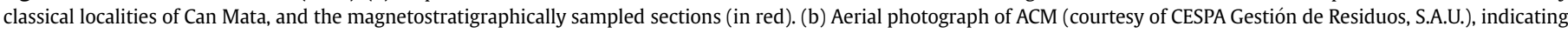

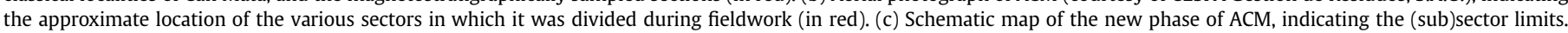

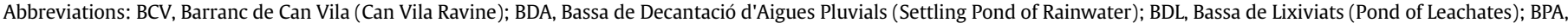

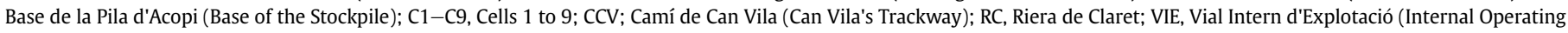
Road). (For interpretation of the references to colour in this figure legend, the reader is referred to the web version of this article.) 
et al., 2009b). The mudstone-dominated alluvial successions at ACM show evidence of soil formation at varying intensities, and are characterized by the widespread presence of early diagenetic carbonates as well as by the alternation of differently colored (pale tan, red-brown, grayish, or mottled) layers (Alba et al., 2009). These multicolored sediments are interpreted as the result of alternating reducing/oxidizing conditions (due to oscillations of the water table), with comparatively thin and scarce paleosol horizons being characterized by an intense red coloration. Additional information about the geology of the ACM can be found in Alba et al. (2009).

\section{Materials and methods}

\subsection{Lithostratigraphic correlation}

A composite lithostratigraphic sequence of ACM was constructed on the basis of 38 local sections $(47.2 \mathrm{~m}$ in average thickness, but ranging from 7 to $150 \mathrm{~m}$ ), five of which have associated paleomagnetic data. Although a simplified correlation of the then available lithostratigraphic sections was provided by Alba et al. (2009), the complete lithostratigraphic panel (including correlation of all the local sections) remained unpublished. All the documented lithostratigraphic sections largely overlap with adjacent ones and were correlated with one another based on 42 correlation levels (See Supplementary Online Material [SOM] Table S1 and Fig. S1). The same method (although not explicitly described) was applied by Moyà-Solà et al. (2009b) to the then available sections.

The levels used to correlate the local sections with one another are composed of fine- to very fine-grained sediments (claystones and siltstones), with some sporadic presence of quartzite clasts and frequently also with pedogenic carbonate nodules. These levels do not differ noticeably in lithology from other argillaceous and silty layers from the area, but can be readily distinguished from them because of their intense red coloration, which is distinctly darker than that of most other fine-grained sediments from the ACM sequence. These correlation levels are interpreted as paleosols, with their intense red coloration denoting well aerated (oxidizing) and lowered water table conditions (Alba et al., 2009). Among the correlation levels used by us, only level $\alpha$ stands out due to its bluish-grayish coloration, which uniquely along the ACM section indicates exceptionally marked reducing and elevated water table conditions (which were otherwise generally absent from this depositional environment). Stratigraphic layers consisting of sandstones or conglomerates were discarded as correlation levels at ACM because of their restricted (decametric) lateral continuity compared to the above-mentioned claystone and siltsone correlation levels (which display a lateral continuity in the order of hundreds of meters within the excavated area). This is exemplified by the above-mentioned level $\alpha$, which is documented in twelve local sections and displays a minimum lateral extension of $>600 \mathrm{~m}$ within the ACM area. This and other correlation levels were repeatedly documented in the successive cells and other structures of the dump as they were consecutively excavated (SOM Table S1), thanks to the extensive outcrops generated by the activity of the heavy machinery (Fig. 2).

\subsection{Magnetostratigraphy}

The magnetostratigraphic correlation of the composite lithostratigraphic sequence of the ACM with the latest update of the Geomagnetic Polarity Time Scale (GPTS; Ogg, 2012) is based on 366 paleomagnetic samples, taken at $1-2 \mathrm{~m}$ intervals from the ACM and the adjacent sections (see results reported in Moyà-Solà et al., 2009b). In particular, Moyà-Solà et al. (2009b: Suppl. Fig. 1 and Suppl. Table 1; see also our Fig. 1a) reported the results for the magnetostratigraphic analysis of six different sections: Barranc de Can Vila, Cell 3, Cell 4, and Vial Intern, restricted to the ACM; Camí de Can Vila, further including nearby areas; and Riera de Claret, entirely circumscribed to an area outside the ACM. Moyà-Solà et al. (2009b) depicted only four (instead of six) local polarity magnetostratigraphic sections because the results for Cell 3, Cell 4 and Camí de Can Vila were fused into a single composite section (see Moyà-Solà et al., 2009b: Fig. 3 and Suppl. Figs. 3-4). In the field, the stratigraphic position of each ACM locality was recorded relative to its closest lithostratigraphic section(s), being thus correlated on lithostratigraphic grounds to the composite magnetostratigraphic sequence.

\subsection{Definition of the localities}

Although isolated fossil finds were common during the surveillance of the excavators' activity, most of the recovered fossils (>90\%) come from formally-defined localities, which were designated with a particular name for practical reasons. These formallydefined localities are designated by the ACM acronym, separated by a slash from the (sub)sector acronym (Fig. 1b,c), and followed by one or two characters denoting the locality (see SOM Table S2 for further details). These localities are restricted areas within a single stratigraphic horizon (usually between 0.2 and $1 \mathrm{~m}$ in thickness) from which fossil remains were collected, being quite heterogeneous in lateral extension and number of recovered fossil remains. Some localities (e.g., ACM/C1-E*) yielded only a single or a few fossil remains, but were nonetheless formally defined given the significance of the finds. Other localities are medium to large-sized accumulations of micro- and/or macrovertebrate remains. Localities that exclusively yielded microvertebrate remains are usually restricted to a few square meters, but the number of recovered remains may range from a few tens to several thousands of specimens. Localities with large mammal remains are also heterogeneous in extension, ranging from small accumulations of a few square meters and less than a hundred recovered remains, to very rich and extensive accumulations of $>100 \mathrm{~m}^{2}$ and $>5000$ macromammal (and often also micromammal) remains.

\subsection{Estimation of locality age by interpolation}

An estimated age was calculated for each locality using linear interpolation from subchron boundaries (e.g., Barry et al., 2002; see also Casanovas-Vilar et al., 2014: Fig. 3), i.e., by relying on the locality's correlation with a particular subchron, its stratigraphic position within that subchron, and the sedimentation rate computed for that subchron, with sedimentation rate being calculated on the basis of the temporal duration and stratigraphic thickness of each subchron in the composite magnetostratigraphic sequence. For the top subchron at ACM, sedimentation rate was computed based on its actual thickness (taking into account nearby outcrops outside the ACM), whereas for the bottom one, sedimentation rate was approximated by that of the adjacent subchron. Due to the intermittent nature of sediment deposition in fluvial/ alluvial environments, characterized by short episodes of sedimentation separated by longer hiatuses, computed sedimentation rates vary depending on the time-scale of observation (Sadler, 1981, 1999) and interpolated ages are prone to some error due to shortterm variation in sedimentation rates (Badgley et al., 1986). Barry et al.'s (2002) method tries to minimize this problem by relying on sedimentation rates calculated for each subchron, although some error remains due to potentially uneven sedimentation rates within each subchron. However, if hiatuses are randomly distributed and short relative to interval duration, age estimates are considered reliable (Badgley et al., 1986; Barry et al., 2002). The 

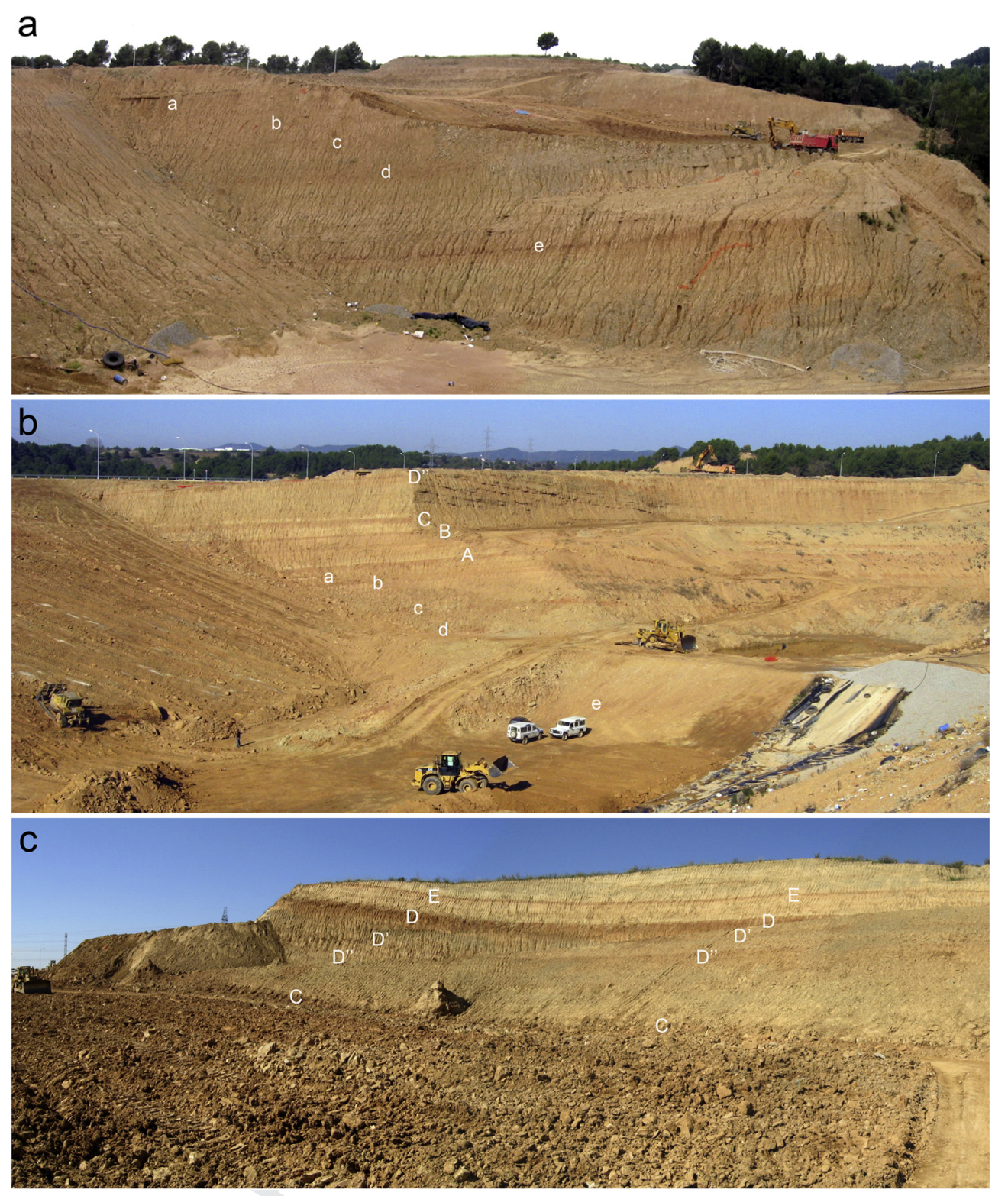

$$
3
$$
5 6

lateral consistency in the measured thickness of stratigraphic intervals, the lack of sharp stratigraphic contacts and the overall uniformity of sedimentary facies across the study area suggest that steady sedimentation at the time-scale of $100 \mathrm{ka}$ is reasonable. The latter assertion was further tested by computing differences in stratigraphic thickness between consecutive correlation levels among different subsections in the composite lithostratigraphic correlation panel, and using their average value multiplied by average sedimentation rate as a proxy of the average error of the age estimates computed for the localities.

\section{Results}

The strata excavated at ACM consistently displayed a moderate dip toward the west (Moyà-Solà et al., 2009b). In particular, repeated field measurements at different outcrops delivered values of strike and dip around $175^{\circ} / 14^{\circ} \mathrm{W}$. Given that most of the cells and structures of the dump were consecutively excavated toward the northwest, over the years progressively younger sediments were sampled. The large overlap between the extensive outcrops generated by the heavy machinery enabled us to reliably correlate all the various local stratigraphic sections with one another, as well as with the magnetostratigraphic sections already sampled by Moyà-Solà et al. (2009b), by means of the above-described correlation levels (see SOM Table S1), which could be followed across successive cells of the dump.

The local composite stratigraphic sequence of ACM has a thickness of $234 \mathrm{~m}$ and covers up to seven subchrons (from C5Ar.1r to $\mathrm{C} 5 \mathrm{r} .2 \mathrm{r}$; Table 1), with an estimated total duration of $1.2 \mathrm{myr}$ (from 12.58 to $11.38 \mathrm{Ma}$; Fig. 3). Along this sequence, 235 formally defined paleontological localities have been discovered, resulting in an average of 19.6 localities per 0.1 myr. Only 19 localities (8\%) have yielded primate remains, belonging to either pliopithecoids or hominoids; $;$ Table 2; Fig. 3). The estimated ages and stratigraphic

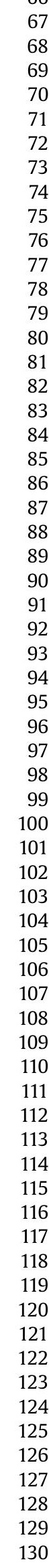


Table 1

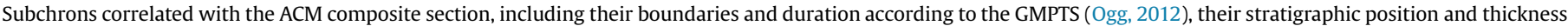
in the composite section, and their computed within-subchron sedimentation rate.

\begin{tabular}{|c|c|c|c|c|c|c|c|}
\hline Subchron & Bottom (Ma) & Top (Ma) & Duration (myr) ${ }^{a}$ & Bottom (m) & Top (m) & Thickness (m) & Sedimentation $(\mathrm{cm} / \mathrm{kyr})^{\mathrm{a}}$ \\
\hline C5r.2r & 11.592 & 11.188 & 0.404 & 204.2 & $261.2^{\mathrm{b}}$ & $57.0^{\mathrm{a}}$ & $14.1^{\mathrm{b}}$ \\
\hline C5r.2n & 11.657 & 11.592 & 0.065 & 177.1 & 204.2 & 27.1 & 41.7 \\
\hline C5r.3r & 12.049 & 11.657 & 0.392 & 84.1 & 177.1 & 93.0 & 23.7 \\
\hline C5An.1n & 12.174 & 12.049 & 0.125 & 68.6 & 84.1 & 15.5 & 12.4 \\
\hline C5An.1r & 12.272 & 12.174 & 0.098 & 47.2 & 68.6 & 21.4 & 21.8 \\
\hline C5An.2n & 12.474 & 12.272 & 0.202 & 15.9 & 47.2 & 31.3 & 15.5 \\
\hline C5Ar.1r & 12.735 & 12.474 & 0.261 & - & 15.9 & $\geq 16$ & - \\
\hline
\end{tabular}

${ }^{\mathrm{a}} \mathrm{myr}=$ millions of years; $\mathrm{kyr}=$ thousands of years.

b Only the lower portion of this subchron $(30 \mathrm{~m})$ is recorded within the ACM, but the top is recorded in the nearby sequence of Camí de Can Vila.

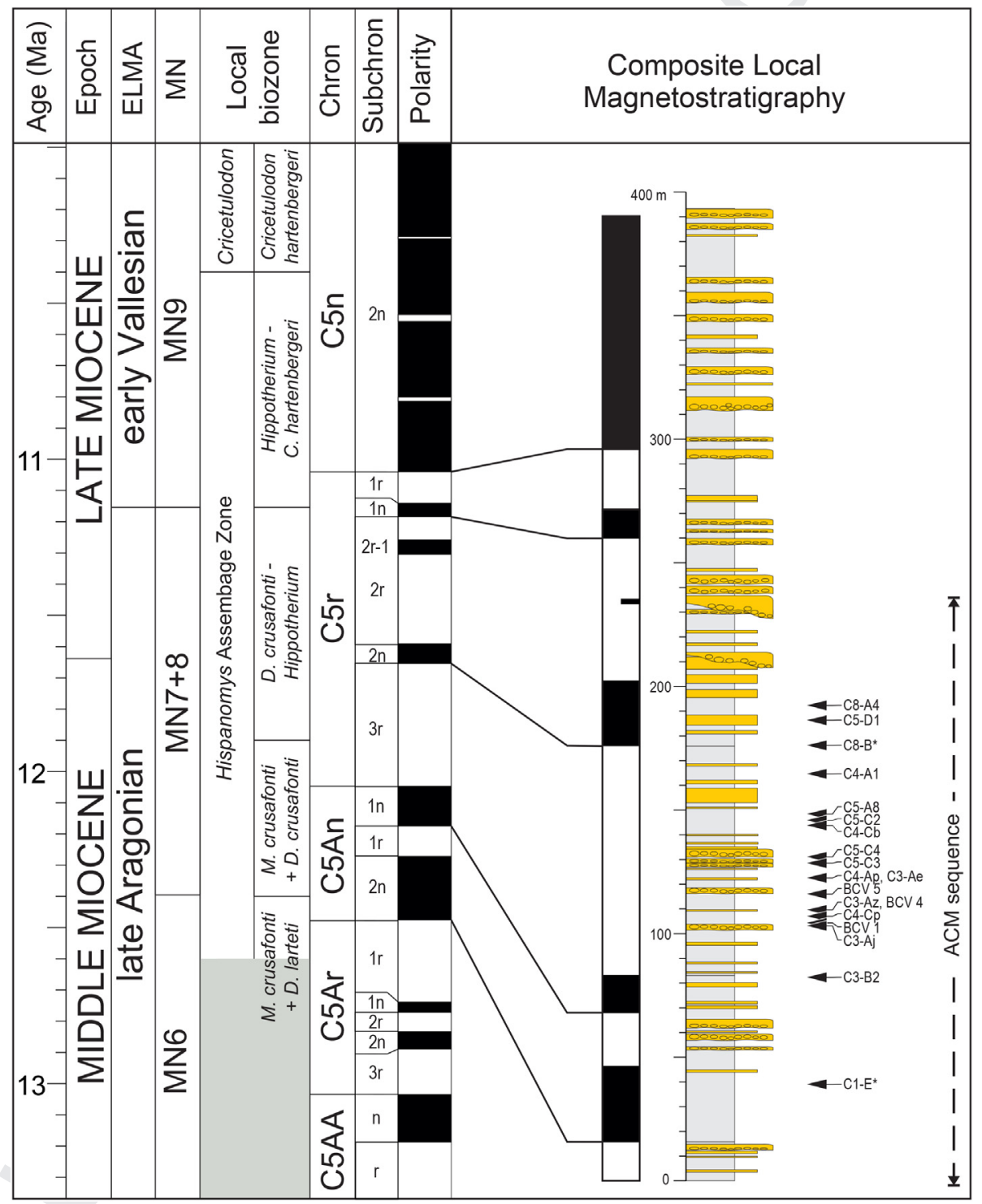

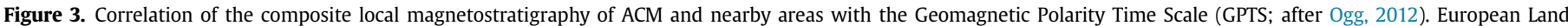

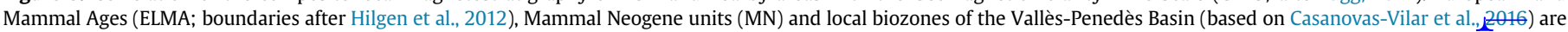

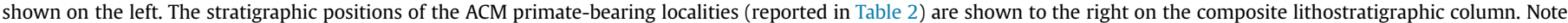
that the bottom boundary of the lowermost local biozone is unknown.

positions in the composite stratigraphic sequence of the primatebearing localities are reported in Table 2, together with remarks on the recovered remains and their taxonomic assignment. A complete list with the stratigraphic position and the estimated ages of all formally defined ACM localities is reported in SOM Table S2. Interpolated ages are subject to two kinds of errors resulting from variations in accumulation rate in both time and space. Variations through time are obvious when sedimentation rates are computed 
Table 2

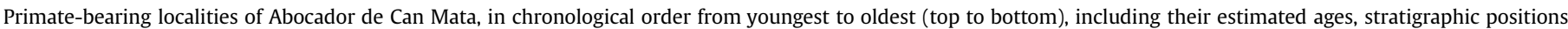
along the synthetic ACM section, and the recorded primate taxa with main descriptive references. ${ }^{a}$

\begin{tabular}{|c|c|c|c|c|c|}
\hline Locality & Age (Ma) & Position (m) & Taxon & Description & References $^{\mathrm{b}}$ \\
\hline $\mathrm{ACM} / \mathrm{C} 8-\mathrm{A} 4^{\mathrm{C}}$ & 11.6 & 194 & Pliobates cataloniae & Cranium with partial skeleton & 1 \\
\hline ACM/C5-D1 & 11.6 & 188 & Pliobates cataloniae & Maxillary fragment and isolated dental remains & 0 \\
\hline ACM/C5-D1 & 11.6 & 188 & Dryopithecinae indet. & Eroded fragment of distal humeral epiphysis & 0 \\
\hline $\mathrm{ACM} / \mathrm{C} 8-\mathrm{B}^{*}$ & 11.7 & 178.5 & Dryopithecinae indet. & Talus & 0 \\
\hline $\mathrm{ACM} / \mathrm{C} 4-\mathrm{A} 1^{\mathrm{C}}$ & 11.7 & 166 & Pliopithecus canmatensis & Male mandible and isolated dental remains & 2 \\
\hline $\mathrm{ACM} / \mathrm{C} 5-\mathrm{A} 8$ & 11.8 & 150 & Pliopithecus canmatensis & $\begin{array}{l}\text { Male and female maxillary fragments, and } \\
\text { isolated dental remains }\end{array}$ & $0,2,3$ \\
\hline $\mathrm{ACM} / \mathrm{C} 5-\mathrm{C} 2$ & 11.8 & 146 & Pliopithecus canmatensis & Upper deciduous premolar & 2 \\
\hline $\mathrm{ACM} / \mathrm{C} 4-\mathrm{Cb}$ & 11.8 & 145 & Pliopithecus canmatensis & $\begin{array}{l}\text { Female (?) mandibular fragments and isolated } \\
\text { dental remains }\end{array}$ & 2 \\
\hline $\mathrm{ACM} / \mathrm{C} 5-\mathrm{C} 4$ & 11.8 & 133 & Pliopithecus canmatensis & Partial phalanx & 0,3 \\
\hline $\mathrm{ACM} / \mathrm{C} 5-\mathrm{C} 3$ & 11.9 & 129 & Pliopithecus canmatensis & $\begin{array}{l}\text { Maxillary fragment, male mandible, isolated dental } \\
\text { remains, cranial fragment, humeral and femoral shafts, } \\
\text { partial metatarsal, and phalangeal fragments }\end{array}$ & $0,2,3$ \\
\hline $\mathrm{ACM} / \mathrm{C} 5-\mathrm{C} 3$ & 11.9 & 129 & Dryopithecinae indet. & Partial manual middle phalanx & \\
\hline $\mathrm{ACM} / \mathrm{C} 3-\mathrm{Ae}$ & 11.9 & 125 & Dryopithecus fontani & Muzzle & 4,5 \\
\hline ACM/C4-Ap & 11.9 & 124 & Dryopithecus fontani & Male upper canine and two phalangeal fragments & 0,6 \\
\hline ACM/BCV5 & 11.9 & 117 & Pliopithecus canmatensis & Phalangeal fragment & 0 \\
\hline $\mathrm{ACM} / \mathrm{C} 3-\mathrm{Az}$ & 11.9 & 110 & cf. Dryopithecus fontani & Partial femur & 4,5 \\
\hline $\mathrm{ACM} / \mathrm{BCV} 4^{\mathrm{e}}$ & 11.9 & 110 & cf. Pierolapithecus catalaunicus & Mandibular fragment & 0 \\
\hline $\mathrm{ACM} / \mathrm{C} 4-\mathrm{Cp}^{\mathrm{f}}$ & 12.0 & 108 & Anoiapithecus brevirostris & Male upper canine and cheek teeth & 0 \\
\hline $\mathrm{ACM} / \mathrm{BCV} 1^{\mathrm{C}}$ & 12.0 & 105 & Pierolapithecus catalaunicus & Face with partial skeleton & $5,7-11$ \\
\hline $\mathrm{ACM} / \mathrm{C} 3-\mathrm{Aj}^{\mathrm{C}}$ & 12.0 & 104 & Anoiapithecus brevirostris & Male face with mandible & $5,12,13$ \\
\hline $\mathrm{ACM} / \mathrm{C} 3-\mathrm{B} 2$ & 12.1 & 83 & Pliopithecoidea indet. & Upper third molar & 14 \\
\hline $\mathrm{ACM} / \mathrm{C} 1-\mathrm{E}^{*}$ & $12.4-12.3^{\mathrm{d}}$ & $34-46$ & Anoiapithecus brevirostris & Maxillary fragments & 13 \\
\hline
\end{tabular}

${ }^{\text {a }}$ Localities with a designation ending in a number (e.g., ACM/BCV1) also have micromammal remains, whereas asterisks (e.g., ACM/C1-E*) denote isolated primate finds. See SOM Table S2 for further details and for the estimated ages of localities without primates.

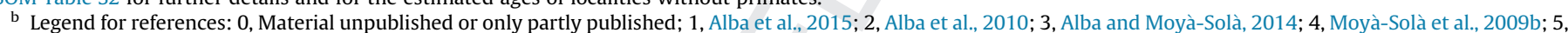

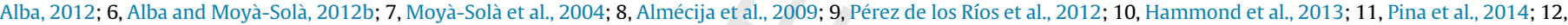
Moyà-Solà et al., 2009a; 13, Alba et al., 2013; 14, Alba et al., 2012.

c Type localities.

d Uncertainties in stratigraphic position preclude a more secure dating.

e Attributed to Hominidae indet. by Alba (2012), but potentially belonging to Pierolapithecus catalaunicus, based on occlusal and endostructural similarities (Fortuny et al., 2014 and unpublished data).

${ }^{\mathrm{f}}$ Attributed to Hominidae indet. by Alba (2012), but assigned here to Anoiapithecus based on canine morphology (for further details, see Alba and Moyà-Solà, 2012b; Alba et al., 2013).

separately for each subchron (Table 1 ), which contributes significantly in minimizing errors in estimated age, as explained in the Materials and methods. Although there is some variation in sedimentation rates between subchrons, the resulting average sedimentation rate of $19.5 \mathrm{~cm} / \mathrm{kyr}$ for the ACM sequence is very similar to the average of $20 \mathrm{~cm} / \mathrm{kyr}$ computed by Garcés et al. (1996) for the Vallesian sections of the same basin.

With regard to errors in estimated ages due to spatial variation in sedimentation rates, they are minimized by the fact that all the correlated local sections come from a very restricted geographic area (less than $0.5 \mathrm{~km}^{2}$ ). This notwithstanding, the correlated local stratigraphic sections do show some minor variations in stratigraphic thickness between synchronous pairs of points, which inevitably results in some degree of uncertainty in estimated ages interpolated from the composite magnetostratigraphic correlation. The average error in estimated ages due to this factor can be approximated based on differences in stratigraphic thickness between consecutive correlation levels. We computed these differences for 221 pairs of consecutive correlation levels, resulting in an average stratigraphic distance of $5.3 \mathrm{~m}$ (range 1-12 m), which on the basis of the average sedimentation rate computed for the whole composite sequence would represent an average error in estimated age of ca. $27 \mathrm{kyr}$ (range 5-62 kyr). Even if this figure should be increased to some extent because of intrasubchron temporal variation in sedimentation rate, it strongly suggests that our estimated ages are reliable at least to the nearest $0.1 \mathrm{Ma}$.

When biostratigraphic data are also taken into account, it emerges that the whole ACM sequence is late Aragonian in age, its lower-most portion being correlated to MN6 and the rest to
MN7+8 (the boundary between these zones being locally estimated at $12.4 \mathrm{Ma}$, as defined by the first appearance of Megacricetodon ibericus; Casanovas-Vilar et al., 2016). According to the latest rodent-based local biozonation of the Vallès-Penedès Basin (Casanovas-Vilar et al., 2015,2016 ), the ACM sequence spans three subzones of the Hispanomys Assemblage Zone: the lower-most part of the sequence is correlated with the Megacricetodon crusafonti + Democricetodon larteti Concurrent Range Subzone ( $\geq 12.6-12.38 \mathrm{Ma}$ ), followed by the $M$. crusafonti - Democricetodon crusafonti Interval Subzone $(12.38-11.87 \mathrm{Ma})$, and finally the D. crusafonti - Hippotherium Interval Subzone (11.87-11.18 Ma). The upper part of the last, shortly after the middle/late Miocene transition at $11.625 \mathrm{Ma}$ (Hilgen et al., 2012), is not recorded at ACM, although it would be represented by the classical locality of Can Mata 1 (ca. 11.2-11.1 Ma; Casanovas-Vilar et al., 2011a). The Dryopithecus molar found by Guerín in the 1920s is also probably younger than the whole ACM sequence, whereas the outcrops of the classical locality of Can Vila are most likely equivalent to sector ACM/BCV, with an estimated age of ca. 12.0 Ma (Alba et al., 2013).

\section{Discussion and conclusions}

The primate succession at ACM is summarized in Figure 4. The oldest primate specimen recorded at ACM corresponds to maxillary remains of Anoiapithecus brevirostris, with an estimated age of 12.4-12.3 Ma, followed by an indeterminate pliopithecoid at 12.1 Ma. Slightly later, most of the remaining great ape finds are clumped in a short time interval between 12.0 and $11.9 \mathrm{Ma}$, including Anoiapithecus (12.0 Ma), Pierolapithecus (12.0 Ma and, 


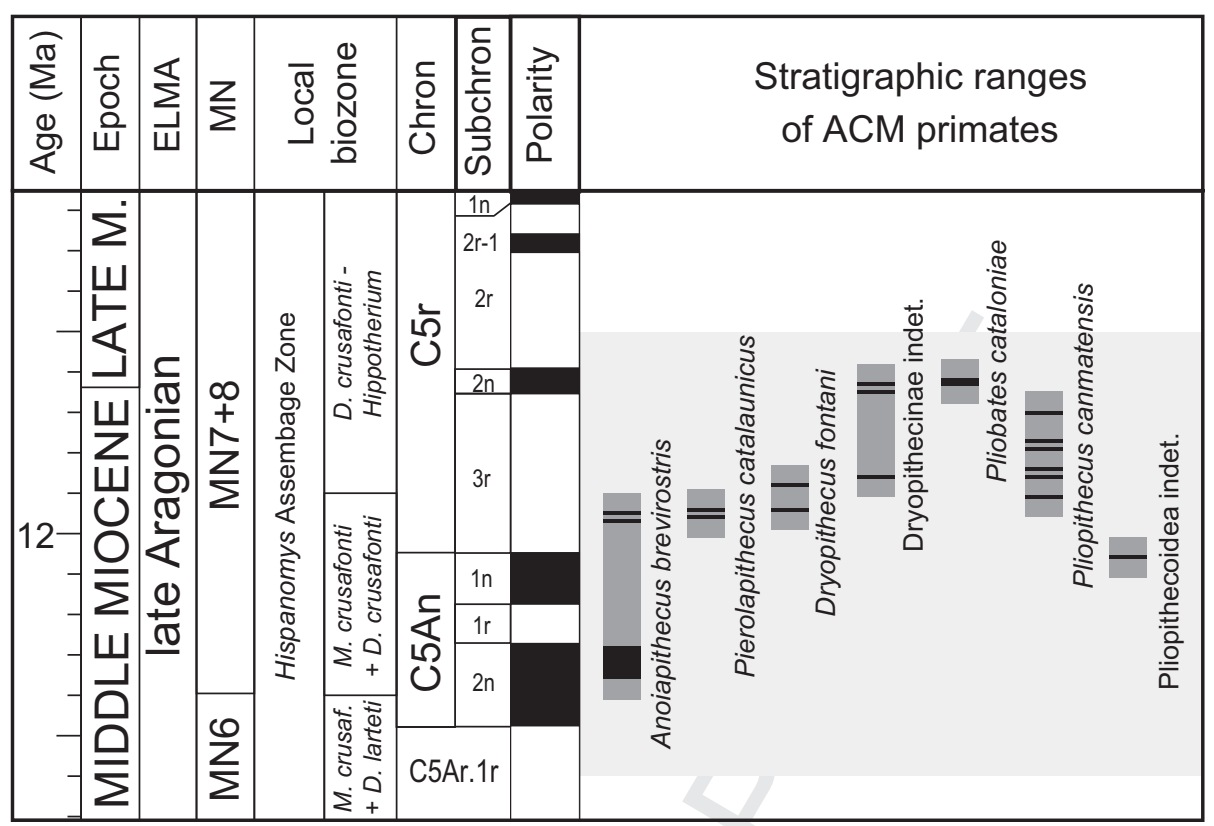

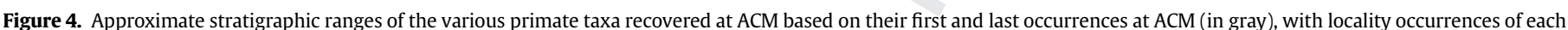

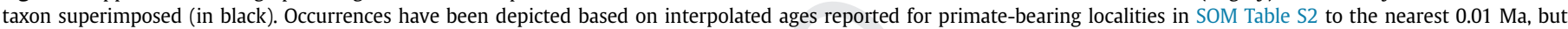

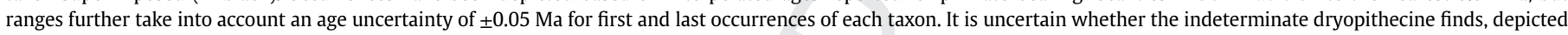

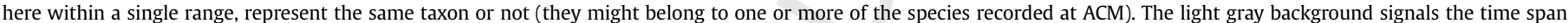
represented by the ACM composite sequence.

tentatively, 11.9 Ma), and Dryopithecus (12.0-11.9 Ma). Only the last taxon and fragmentary indeterminate dryopithecine remains minimally overlap with the lower stratigraphic range of the pliopithecoid Pliopithecus canmatensis, which is recorded in seven localities that span from 11.9 to $11.7 \mathrm{Ma}$. Subsequently, two isolated dryopithecine postcranial bones are recorded at ca. 11.7-11.6 Ma, whereas the stem ape Pliobates cataloniae is the youngest primate from the ACM sequence, being recorded in two localities (one unpublished), both with an age of $11.6 \mathrm{Ma}$. Co-occurrence of two different primate taxa within a single locality has been recorded only twice, based on very fragmentary unpublished dryopithecine remains: a partial middle phalanx from ACM/C5-C3 (11.9 Ma), too large to belong to $P$. canmatensis; and a distal humeral fragment from ACM/C5-D1 (11.6 Ma), too large and derived in morphology to belong to $P$. cataloniae. The original stratigraphic ranges of the recorded primate species, in all probability, must have been longer than recorded (about an order of magnitude, judging from published average species durations for fossil mammals; Vrba and DeGusta, 2004; Alroy, 2009), and it is thus most likely that all of them overlapped in time. However, it is noteworthy that pliopithecoids and hominoids, despite overlapping in stratigraphic range at ACM (Fig. 4), only rarely co-occur at the same locality. Therefore, it is uncertain whether these two groups habitually co-existed in both time and space, i.e., whether they frequently inhabited the same type of habitat.

Throughout the European Miocene, pliopithecoids and hominoids co-occur at only a few sites (Begun, 1989; Andrews et al., 1996; Harrison et al., 2002; Eronen and Rook, 2004; Begun et al., 2010; Sukselainen et al., 2015), such as Castell de Barberà in the Vallès-Penedès Basin (Alba et al., 2011b; Almécija et al., 2012; Alba and Moyà-Solà, 2012a), or Rudabánya in Hungary (Ungar, 2005; Begun et al., 2010). However, the co-occurrence of pliopithecoids and hominoids within a single stratigraphic horizon can be proven only for Rudabánya (Begun et al., 2010), whereas at most other sites, such as Castell de Barberà, it is unknown whether pliopithecoid and hominoid remains come from the very same stratigraphic horizon. Here we show that, through the ACM sequence, pliopithecoids and hominoids generally do not co-occur within a single locality (with a single exception), in spite of close similarities in the geological age of the material. This resembles the case previously documented for the complex of karstic sites from La Grive-Saint-Alban (France), where two pliopithecoids and a hominoid are recorded from different fissure fillings (Mein and Ginsburg, 2002; Pérez de los Ríos et al., 2013). In fact, despite the high number of primate taxa recorded at ACM (at least, by European Miocene standards), two different species (a large-bodied dryopithecine and a small-bodied catarrhine, either Pliopithecus or Pliobates) co-occur only twice. Some authors have previously argued that the infrequent co-occurrence between hominoids and pliopithecoids throughout the European Miocene might be, at least in part, a sampling artifact related to the rarity of these primates (Andrews et al., 1996). Alternatively, the rare co-occurrence between these groups at ACM and elsewhere in Europe might be related to differences in the ecological preferences of each group, coupled with changing paleoenvironmental conditions through time. According to the principle of competitive exclusion, these groups might have had different ecological preferences or occupied slightly different ecological niches, thereby only coexisting under particular environmental conditions (Andrews et al., 1996). Since the diet inferred for $P$. canmatensis overlaps with the dietary variation displayed by ACM hominoids as a whole (DeMiguel et al., 2013, 2014; Alba et al., 2015), potential ecological differences between these groups might be more likely related to paleobiological aspects different from diet (e.g., locomotion, life history). Most recently, Sukselainen et al. (2015) concluded that pliopithecoids generally inhabited more humid environments than hominoids. These authors further tentatively suggested that localities with both taxa were even more humid, although these differences were not statistically significant (which is not surprising, given the small number of localities where both groups have been recorded). 
In order to test the two hypotheses mentioned above at ACM, detailed quantitative analyses (outside the scope of this paper) would be required, including the analysis of taphonomic data (such as the number of specimens of each taxon recovered from each locality) to evaluate sampling biases. Given the heterogeneous nature of the formally-defined ACM localities, the role of sampling biases (due to differences in collecting techniques, volume of sediment excavated and/or screen-washed, and richness of the accumulations) cannot be ignored when comparing the taxa recovered from each locality. To some extent, these biases may be minimized by combining localities into stratigraphic bins of equal (0.1 myr) duration. However, sampling effort appears more intense toward the upper part of the ACM sequence (particularly between 12.0 and $11.7 \mathrm{Ma}$ and, especially, at $11.6 \mathrm{Ma}$ ) - at least, as roughly approximated by the number of formally defined localities per 0.1 myr stratigraphic bin (see Table 2) - so that a quantitative correction for sampling biases will, nevertheless, be required. Unfortunately, these analyses will not be possible until a much larger proportion of ACM fossils are prepared (in the case of large vertebrates) or sorted out from the screen-washing residue (regarding small vertebrates). In the meantime, paleoecological analyses based on the ACM fauna (such as the analyses of tooth enamel stable isotopes, or mesowear analysis of ungulate teeth) may provide helpful insights about whether ACM habitats did change significantly with the passing of time and, if so, whether the inferred paleoenvironmental changes are somewhat correlated with the faunal turnovers observed among the recovered fauna (including primates). Therefore, the set of primate-bearing localities from ACM, framed within a densely-sampled sequence spanning about one million years and restricted to a small geographic area, offers the prospect of shedding new light, in years to come, on the most likely cause(s) underpinning the infrequent co-occurrence between large-bodied apes and small catarrhines in the European Miocene. In this regard, the estimated ages reported here for all the fossil vertebrate localities from the ACM stratigraphic sequence represent an important first step towards the resolution of this long-standing conundrum.

\section{Acknowledgments}

Research reported in this work has been funded by the Spanish Ministerio de Economía y Competitividad (CGL2014-54373-P, CGL2014-55900-P and RYC-2013-12470 to ICV) and the Departament d'Innovació, Universitats i Empresa of the Generalitat de Catalunya (2014 SGR 416, GRC). In turn, fieldwork at ACM has been defrayed by CESPA G.R., S.A.U., whereas preparation of the recovered fossils has been partly financed by the Departament de Cultura of the Generalitat de Catalunya (2014/100609). We gratefully thank Jordi Galindo for his pioneering geological work (2002-2006) at $\mathrm{ACM}$, and Salvador Moyà-Solà for discussions about the ACM primates. We further acknowledge the continued collaboration and support of the Servei d'Arqueologia i Paleontologia of the Generalitat de Catalunya during the successive paleontological interventions performed at ACM. Finally, we are grateful to the two anonymous reviewers, whose constructive criticisms and sugges02 tions helped us to improve a previous version of this paper.

\section{Supplementary Online Material}

Supplementary online material related to this article can be found at http://dx.doi.org/10.1016/j.jhevol.2016.09.012.

\section{References}

Agustí, J., Cabrera, L., Moyà-Solà, S., 1985. Sinopsis estratigráfica del Neógeno de la fosa del Vallés-Penedés. Paleontol. Evol. 18, 57-81.

Alba, D.M., 2012. Fossil apes from the Vallès-Penedès Basin. Evol. Anthropol. 21, 254-269.

Alba, D.M., Moyà-Solà, S., 2012a. A new pliopithecid genus (Primates: Pliopithecoidea) from Castell de Barberà (Vallès-Penedès Basin, Catalonia, Spain). Am. J. Phys. Anthropol. 147, 88-112.

Alba, D.M., Moyà-Solà, S., 2012b. On the identity of a hominoid male upper canine from the Vallès-Penedès Basin figured by Pickford (2012c). Estudios Geol. 68, 149-153.

Alba, D.M., Moyà-Solà, S., 2014. New fossil remains of Pliopithecus canmatensis from Abocador de Can Mata, and their implications for the taxonomic validity and phylogenetic position of Epipliopithecus (Primates, Pliopithecidae). Am. J. Phys. Anthropol. 153 (S58), 64.

Alba, D.M., Moyà-Solà, S., Casanovas-Vilar, I., Galindo, J., Robles, J.M., Rotgers, C. Furió, M., Angelone, C., Köhler, M., Garcés, M., Cabrera, L., Almécija, S. Obradó, P., 2006. Los vertebrados fósiles del Abocador de Can Mata (els Hostalets de Pierola, l'Anoia, Cataluña), una sucesión de localidades del Aragoniense superior (MN6 y MN7 +8 ) de la cuenca del Vallès-Penedès. Campañas 2002-2003, 2004 y 2005. Estudios Geol. 62, 295-312.

Alba, D.M., Robles, J.M., Rotgers, C., Casanovas-Vilar, I., Galindo, J., Moyà-Solà, S. Garcés, M., Cabrera, L., Furió, M., Carmona, R., Bertó Mengual, J.V., 2009. Middle Miocene vertebrate localities from Abocador de Can Mata (els Hostalets de Pierola, Vallès-Penedès Basin, Catalonia, Spain): An update after the 2006-2008 field campaigns. Paleolusitana 1, 59-73.

Alba, D.M., Moyà-Solà, S., Malgosa, A., Casanovas-Vilar, I., Robles, J.M., Almécija, S. Galindo, J., Rotgers, C., Bertó Mengual, J.V., 2010. A new species of Pliopithecus Gervais, 1849 (Primates: Pliopithecidae) from the Middle Miocene (MN8) of Abocador de Can Mata (els Hostalets de Pierola, Catalonia, Spain). Am. J. Phys. Anthropol. 141, 52-75.

Alba, D.M., Casanovas-Vilar, I., Robles, J.M., Moyà-Solà, S., 2011a. Parada 3. El Aragoniense superior y la transición con el Vallesiense: Can Mata y la exposición paleontológica de els Hostalets de Pierola. Paleontol. Evol. Mem. Esp. Núm. 6, 95-109.

Alba, D.M., Moyà-Solà, S., Almécija, S., 2011b. A partial hominoid humerus from the middle Miocene of Castell de Barberà (Vallès-Penedès Basin, Catalonia, Spain). Am. J. Phys. Anthropol. 144, 365-381.

Alba, D.M., Moyà-Solà, S., Robles, J.M., Galindo, J., 2012. Brief Communication: The oldest pliopithecid record in the Iberian Peninsula based on new material from the Vallès-Penedès Basin. Am. J. Phys. Anthropol. 147, 135-140.

Alba, D.M., Fortuny, J., Pérez de los Ríos, M., Zanolli, C., Almécija, S., CasanovasVilar, I., Robles, J.M., Moyà-Solà, S., 2013. New dental remains of Anoiapithecus and the first appearance datum of hominoids in the Iberian Peninsula. J. Hum. Evol. 65, 573-584.

Alba, D.M., Almécija, S., DeMiguel, D., Fortuny, J., Pérez de los Ríos, M., Pina, M. Robles, J.M., Moyà-Solà, S., 2015. Miocene small-bodied ape from Eurasia sheds light on hominoid evolution. Science 350, aab2625.

Almécija, S., Alba, D.M., Moyà-Solà, S., 2009. Pierolapithecus and the functional morphology of Miocene ape hand phalanges: paleobiological and evolutionary implications. J. Hum. Evol. 57, 284-297.

Almécija, S., Alba, D.M., Moyà-Solà, S., 2012. The thumb of Miocene apes: new insights from Castell de Barberà (Catalonia, Spain). Am. J. Phys. Anthropol. 148 $436-450$

Alroy, J., 2009. Speciation and extinction in the fossil record of North American mammals. In: Butlin, R.K. Bridle, J.R., Schluter, D. (Eds.), Speciation and Pattern of Diversity. Cambridge University Press, Cambridge, pp. 301-323.

Andrews, P., Harrison, T., Delson, E., Bernor, R.L., Martin, L., 1996. Distribution and biochronology of European and Southwest Asian Miocene catarrhines. In Bernor, R.L., Fahlbusch, V., Mittmann, H.-W. (Eds.), The Evolution of Western Eurasian Neogene Mammal Faunas. Columbia University Press, New York, pp. 168-207.

Badgley, C., Tauxe, L., Bookstein, F.L., 1986. Estimating the error of age interpolation in sedimentary rocks. Nature 319, 139-141.

Barry, J.C., Morgan, M.E., Flynn, L.L., Pilbeam, D., Behrensmeyer, A.K., Mahmood Raza, S., Khan, I.A., Badgley, C., Hicks, J., Kelley, J., 2002. Faunal and environmental change in the late Miocene Siwaliks of Northern Pakistan. Paleobiology 28 (sp. 3), 1-71.

Bataller Calatayud, J.R., 1938. Els Ratadors Fòssils de Catalunya. Impremta de la Casa d'Assistència President Macià, Barcelona.

Begun, D.R., 1989. A large pliopithecine molar from Germany and some notes on the Pliopithecinae. Folia Primatol. 52, 156-166.

Begun, D., Nargolwalla, M.C., Kordos, L., 2010. New catarrhine fossils from Rudabánya (Hungary): Evidence for sympatric primates in a late Miocene swamp forest. Am. J. Phys. Anthropol. 141 (S50), 64.

Cabrera, L., Roca, E., Garcés, M., Porta, J. de, 2004. Estratigrafía y evolución tectonosedimentaria oligocena superior-neógena del sector central del margen catalán (Cadena Costero-Catalana). In: Vera JA. (Ed.) Geología de España. Sociedad Geológica de España/Instituto Geológico y Minero de España, Madrid, pp. 569-573.

Casanovas-Vilar, I., Alba, D.M., Moyà-Solà, S., Galindo, J., Cabrera, L., Garcés, M., Furió, M., Robles, J.M., Köhler, M., Angelone, C., 2008. Biochronological, taphonomical and paleoenvironmental background of the fossil great ape Pierolapithecus catalaunicus (Primates, Hominidae). J. Hum. Evol. 55, 589-603.

Erusafont Pairó and Hürzeler, 1969. 
Casanovas-Vilar, I., Alba, D.M., Garcés, M., Robles, J.M., Moyà-Solà, S., 2011a. Updated chronology for the Miocene hominoid radiation in Western Eurasia. Proc. Natl. Acad. Sci. 108, 5554-5559.

Casanovas-Vilar, I., Alba, D.M., Robles, J.M., Moyà-Solà, S., 2011b. Registro paleontológico continental del Mioceno de la cuenca del Vallès-Penedès. Paleontol. Evol. Mem. Espec. Núm. 6, 55-80.

Casanovas-Vilar, I., Van den Hoek Ostende, L.W., Furió, M., Madern, P.A., 2014. The range and extent of the Vallesian Crisis (Late Miocene): new prospects based on the micromammal record from the Vallès-Penedès basin (Catalonia, Spain). J. Iber. Geol. 40, 29-48.

Casanovas-Vilar, I., Madern, A., Alba, D.M., Cabrera, L., García-Paredes, I., Van den Hoek Ostende, L.W., DeMiguel, D., Robles, J.M., Furió, M., Van Dam, J., Garcés, M. Angelone, $C$. Moyà-Solà, S, 2015. The Miocene mammal record of the VallèsPenedès Basin (Catalonia). C. R. Palevol. h:/dxdoi.org/10.1016 j.crpv.2015.07.004 published online,

asanovas-Vilar, I., Garcés, M., Van Dam, J., García-Paredes, I., Robles, J.M. Alba, D.M., 2016. An updated biostratigraphy for the late Aragonian and the Vallesian of the Vallès-Penedès Basin (Catalonia). Geol. Acta 14, 195-217.

Crusafont Pairó, M., 1944. La sección de paleontología del Museo de Sabadell. Publ. Mus. Sabadell 2, 7-9.

Crusafont Pairó, M., 1958. Nuevo hallazgo del póngido vallesiense Hispanopithecus Bol. Inf. Inst. Paleontol. Sabadell, $13-14,37-41,6-8$,

Crusafont-Pairó, M., Golpe-Posse, J.M., 1973. New pongids from the Miocene of Vallès Penedès Basin (Catalonia, Spain). J. Hum. Evol. 2, 17-23.

Grusafont Pairó, M., Hürzeler, J., 1969. Catálogo-comentado de los póngidos fósiles de España. Acta Geol. Hisp. 4, 44-48.

de Gibert, J.M., Casanovas-Vilar, I., 2011. Contexto geológico del Mioceno de la cuenca del Vallès-Penedès. Paleontol. Evol. Mem. Esp. Núm. 6, 39-45.

DeMiguel, D., Alba, D.M., Moyà-Solà, S., 2013. European pliopithecid diets revisited in the light of dental microwear in Pliopithecus canmatensis and Barberapithecus huerzeleri. Am. J. Phys. Anthropol. 151, 573-582.

DeMiguel, D., Alba, D.M., Moyà-Solà, S., 2014. Dietary specialization during the evolution of Western Eurasian hominoids and the extinction of European great apes. PLoS ONE 9, e97442.

Eronen, J.T., Rook, L., 2004. The Mio-Pliocene European primate fossil record: dy namics and habitat tracking. J. Hum. Evol. 47, 323-341.

Fortuny, J., Zanolli, C., Macchiarelli, R., Bernardini, F., Tuniz, C., Alba, D.M., 2014 Relative enamel thickness and enamel-dentine junction morphology in the Vallès-Penedès hominoids: A 3D approach based on X-ray micro-computedtomography [Abstract]. Am. J. Phys. Anthropol. 153 (S58), 119-120.

Garcés, M., Agustí, J., Cabrera, L., Parés, J.M., 1996. Magnetostratigraphy of the Vallesian (late Miocene) in the Vallès-Penedès Basin (northeast Spain). Earth Planet. Sci. Lett. 142, 381-396.

Golpe Posse, J.M., 1982. Los hispanopitecos (Primates, Pongidae) de los yacimientos del Vallès Penedès (Cataluña - España). I: Material ya descrito. Butll. Inf. Inst. Paleontol. Sabadell 14, 63-69.

Golpe Posse, J.M., 1993. Los Hispanopitecos (Primates, Pongidae) de los yacimientos del Vallès-Penedès (Cataluña, España). II: Descripción del material existente en el Instituto de Paleontología de Sabadell. Paleontol. Evol. 26-27, 151-224.

Hammond, A.S., Alba, D.M., Almécija, S., Moyà-Solà, S., 2013. Middle Miocene Pierolapithecus provides a first glimpse into early hominid pelvic morphology. J. Hum. Evol. 64, 658-666.

Harrison, T., van der Made, J., Ribot, F., 2002. A new middle Miocene pliopithecid from Sant Quirze, northern Spain. J. Hum. Evol. 42, 371-377.

Hilgen, F.J., Lourens, L.J., Van Dam, J.A., Beu, A.G., Boyes, A.F., Cooper, R.A., Krijgsman, W., Ogg, J.C., Piller, W.E., Wilson, D.S., 2012. The Neogene period. In:
Gradstein, F.M., Ogg, J.G., Schmitz, M.D., Ogg, G.M. (Eds.), The Geologic Time Scale 2012, vol. 2. Elsevier, Amsterdam, pp. 923-978.

Mein, P., Ginsburg, L., 2002. Sur l'âge relatif des différents dépôts karstiques miocènes de La Grive-Saint-Alban (Isère). Cah. Scient. 2/2002, 7-47.

Moyà-Solà, S., Köhler, M., Alba, D.M., Casanovas-Vilar, I., Galindo, J., 2004. Pierolapithecus catalaunicus, a new Middle Miocene great ape from Spain. Science 306, 1339-1344

Moyà-Solà, S., Alba, D.M., Almécija, S., Casanovas-Vilar, I., Köhler, M., De EstebanTrivigno, S., Robles, J.M., Galindo, J., Fortuny, J., 2009a. A unique Middle Miocene European hominoid and the origins of the great ape and human clade. Proc. Natl. Acad. Sci. 106, 9601-9606.

Moyà-Solà, S., Köhler, M., Alba, D.M., Casanovas-Vilar, I., Galindo, J., Robles, J.M. Cabrera, L., Garcés, M., Almécija, S., Beamud, E., 2009b. First partial face and upper dentition of the Middle Miocene hominoid Dryopithecus fontani from Abocador de Can Mata (Vallès-Penedès Basin, Catalonia, NE Spain): taxonomic and phylogenetic implications. Am. J. Phys. Anthropol. 139, 126-145.

Ogg, J.G., 2012. Geomagnetic polarity time scale. In: Gradstein, F.M., Ogg, J.G., Schmitz, M.D., Ogg, G.M. (Eds.), The Geologic Time Scale 2012, vol. 1. Elsevier, Amsterdam, pp. 85-113.

Pérez de los Ríos, M., Moyà-Solà, S., Alba, D.M., 2012. The nasal and paranasal architecture of the Middle Miocene ape Pierolapithecus catalaunicus (Primates: Hominidae): Phylogenetic implications. J. Hum. Evol. 63, 497-506.

Pérez de los Ríos, M., Alba, D.M., Moyà-Solà, S., 2013. Taxonomic attribution of the La Grive hominoid teeth. Am. J. Phys. Anthropol. 151, 558-565.

Pina, M., Almécija, S., Alba, D., O'Neil, M.C., Moyà-Solà, S., 2014. The Middle Miocene ape Pierolapithecus catalaunicus exhibits extant great ape-like morphometric affinities on its patella: Inferences on knee function and evolution. PLoS ONE 9, e91944.

Sadler, P.M., 1981. Sediment accumulation rates and the completeness of stratigraphic sections. J. Geol. 89, 569-584.

Sadler, P.M., 1999. The influence of hiatuses on sediment accumulation rates. In: Bruns, P., Hass, H.C. (Eds.), On the Determination of Sediment Accumulation Rates. Trans Tech Publications, Zurich, pp. 15-40.

Sukselainen, L., Fortelius, M., Harrison, T., 2015. Co-occurrence of pliopithecoid and hominoid primates in the fossil record: An ecometric analysis. J. Hum. Evol. 84, 25-41.

Ungar, P.S., 2005. Dental evidence for the diets of fossil primates from Rudabánya northeastern Hungary with comments on extant primate analogs and "noncompetitive" sympatry. Palaeontogr. Ital. 90, 97-111.

van der Made, J., Ribot, F., 1999. Additional hominoid material from the Miocene of Spain and remarks on hominoid dispersals into Europe. Contrib. Tert. Quat. Geol. 36, 25-39.

Villalta Comella, J.F. de, Crusafont Pairó, M., 1941a. Los vertebrados fósiles del Mioceno continental del Vallés-Penedés (provincia de Barcelona). Publ. Mus. Sabadell 1,1-16.

Villalta Comella, J.F. de, Crusafont Pairó, M., 1941b. Hallazgo del “Dryopithecus fontani”, Lartet, en el Vindoboniense de la cuenca Vallés-Penedés. Bol. Inst. Geol. Min. Esp. 55, 131-142.

Villalta Comella, J.F. de, Crusafont Pairó, M., 1944. Dos nuevos antropomorfos del Mioceno español y su situación dentro de la moderna sistemática de los símidos. Not. Com. Inst. Geol. Min. Esp. 13, 1-51.

Villalta, J.F. de, Crusafont, M., 1946. Les gisements de Mammifères du Néogène espagnol. II. Bassin de Vallès-Pénadès (Catalogne), Vindobonien, Hostalets de Pierola. C. R. Som. Soc. Geol. Fr. 1946, 133-134.

Vrba, E.S., DeGusta, D., 2004. Do species populations really start small? New perspectives from the Late Neogene fossil record of African mammals. Phil. Trans. R. Soc. B 359, 285-293.
47 